\title{
BANKOVNÍ RIZIKA JAKO DETERMINANTY ČISTÉ ÚROKOVÉ MARŽE V BANKOVNÍM SEKTORU ČESKÉ REPUBLIKY
}

\author{
Marek Dohnal
}

\section{Klíčová slova:}

čistá úroková marže, kreditní riziko, likviditní riziko, úrokové riziko, kapitálové riziko, panelová regrese s fixními efekty

\section{Key words:}

net interest margin, credit risk, liquidity risk, interest risk, capital risk, panel regression with fixed effects

\begin{abstract}
Abstrakt
Článek zkoumá vliv vybraných bankovních rizik na čistou úrokovou marži (NIM) bank z českého bankovního sektoru. Je odhadován potenciální vliv kreditního, likviditního, úrokového a kapitálového rizika na čistou úrokovou marži bank. Analýza je provedena na ročních panelových datech bank České republiky v období let 2000-2009. Klíčovou metodou zkoumání je panelová regrese s fixními efekty. Z výsledků empirických testů vyplývá, že vybraná rizika nejsou významnými determinanty čisté úrokové marže. Odhady ukazují, že růst kapitálového rizika způsobuje zvýšení čisté úrokové marže. Naopak s růstem rizika likviditního je spojeno snížení čisté úrokové marže.
\end{abstract}

\begin{abstract}
The article explores the influence of the selected banking risks on the net interest margin (NIM) of banks in the Czech banking sector. The study estimates potential impact of credit, liquidity, interest and capital risks on the net interest margin. The analysis is carried out with the annual panel data of the Czech Republic banks in the period from 2000 to 2009. Panel regression with fixed effects was used as a key method. From the results of empirical tests it is obvious that the selected risks are not significant determinants of the net interest margin. The estimations acknowledge that the growth of the capital risk causes increase in the net interest margin. Whereas the growth of the liquidity risk is connected with decrease in the net interest margin.
\end{abstract}

\section{Úvod}

Bankovní podnikání a výnosy jsou jako každá podnikatelská činnost ohroženy celou řadou rizik, kterými je obecně rozuměno nebezpečí vzniku škody. Na rozdíl od nejistoty je u rizika možné odhadnout pravděpodobnost jejich výskytu. ${ }^{1}$ Banka je ohrožena nejen běžnými podnikatelskými riziky, ale také riziky finančními, které souvisejí s jejich potenciální finanční ztrátou. S rozvojem bankovnictví obecně i s rozvojem nových služeb a produktů vznikají nejen stále nová a nová rizika, ale současně se rož̌iřují i možnosti bank zajistit se proti případným ztrátám. Na tato rizika je soustředěna mimořádná pozornost odborné veřejnosti i bankovního dohledu a jsou patrné tendence ke sjednocování regulace na mezinárodním základě. ${ }^{2}$ Při procesu posuzování rizik v bankovním sektoru lze vycházet z myšlenky, že riziko velice úzce souvisí s výnosy. Tato souvislost vyzývá kanalýze a prozkoumání vzájemné vazby rizika a výnosů.

\footnotetext{
${ }^{1}$ JÍLEK, J. Finanční rizika, Praha: GRADA Publishing, 2000, s. 15. ISBN 80-247-9015-7.

${ }^{2}$ POLOUČEK, S. a kol. Bankovnictví, Praha: C. H. Beck, 2006, s. 282-285. ISBN 80-7179-462-7.
} 
Cílem studie je zkoumat vliv vybraných bankovních rizik na čistou úrokovou marži bank z celého bankovního sektoru České republiky a nalézt odpověd’ na otázku, jsou-li vybraná rizika významným determinantem čisté úrokové marže a je-li s jejich růstem spojeno zvýšení či snížení čisté úrokové marže. Za účelem splnění cíle je práce rozdělena do tř́ základních kapitol. První kapitola je věnována stručnému představení základní metody zkoumání, kterou je panelová regrese a jsou zde ve stručnosti představeni autoři, zabývající se vlivem rizik na čistou úrokovou marži. $\mathrm{V}$ druhé kapitole jsou vymezena použitá data a jsou představeny ukazatele včetně jejich konstrukce. Zpracování třetí kapitoly je zaměřeno na vlastní analýzu vlivu vybraných rizik na čistou úrokovou marži. Je zde popsán odhadovaný ekonometrický model, dále jsou zde souhrnně prezentovány výsledky odhadovaného modelu a je provedeno srovnání se závěry předešlých studií. V závěru jsou sumarizovány dílčí poznatky, doplněné o stručnou diskuzi na téma Basel III a jeho možné dopady na čistou úrokovou marži v souvislosti s kapitálovým a likviditním rizikem. Je zde zároveň otevřen prostor pro další zkoumání v této oblasti.

\section{Empirická analýza}

Cílem empirické analýzy je zanalyzovat a prozkoumat závislost mezi vysvětlující proměnnou (ukazatelé reprezentující skupiny vybraných bankovních rizik) a vysvětlovanou proměnnou (čistou úrokovou marží). Analýza je metodologicky založena na prŕístupech zahraničních autorů, kteří zkoumali vliv, vztahy a závislost celé škály rizik a makroekonomických veličin na čistou úrokovou marži bank v různých zemích nebo skupinách zemí, v různém časovém období, s různě dlouhými časovými řadami. Závislostí rizik a čisté úrokové marže se ve svých studiích mj. zabývali autoři Angbanzo (Commercial bank net interest margins, default risk, interest-rate risk and off-balance sheet banking), Claeys a Vennet (Determinants of bank interest margins in Central and Eastern Europe: A comparison with the West), Drakos (Assessing the success of reform in transition banking 10 years later: an interest margins analysis), dále např. Ho a Saunders (The determinants of banks interest margins: Theory and empirical evidence) a autoři Kasman, Tunc, Vardar a Okan (Consolidation and commercial bank net interest margins: Evidence from the old and new European Union members and candidate countries).

S ohledem na cíl studie bude jako základní metoda zkoumání aplikována panelová regrese, která umožňuje analýzu i náhodných, skrytých skutečností ve strukturách vztahů mezi veličinami, které by př̀i použití jednoduché regrese nebyly zachyceny. ${ }^{3}$

K modelování budou použita panelová data, odhad modelu bude proveden v ekonometrickém prostředí Eviews 7.

Nezbytnou součástí regresní analýzy je provedení diagnostických testů reziduálních složek a testování jejich klíčových charakteristik: normality, multikolinearity a absence autokorelace. Normalita je testována pomocí Jarque-Berova testu, multikolinearita využitím korelační matice a autokorelace je zjišt’ována pomocí koeficientu Durbin-Watsonova testu.

Za účelem zjištění charakteru časové řady je nutné před zahájením ekonometrické analýzy u všech časových řad zkoumat jejich stacionaritu, tj. přítomnost jednotkového kořene. ${ }^{4}$

\footnotetext{
${ }^{3}$ NOVÁK, P. Analýza panelových dat, Praha: Acta Oeconomica Pragensia, 2007, roč. 15, č. 1, s. 71 - 78. ISSN 0572-3043.

${ }^{4}$ VODOVÁ, P. Modelování trhu úvěrů v České republice, Karviná: SU-OPF v Karviné, 2009, s. 62. ISBN 97880-7248-539-0.
} 
K tomuto účelu jsou použity panelové testy jednotkového kořene pro všechny proměnné: LLC, Breitung, IPS, Fisher ADF, Fisher PP a Hadri testy. ${ }^{5}$

\section{Použitá data}

Panel dat je tvořen 21 bankami, kterým byla udělena bankovní licence Českou národní bankou. Pobočky zahraničních bank, stavební spořitelny, banky v nucené správě, banky bez licence a další subjekty pohybující se na finančním trhu nejsou do tohoto panelu zařazeny. Analýza se bude týkat dat z let 2000 - 2009, data z roku 2010 v době zpracování ještě nebyla $\mathrm{k}$ dispozici. $\mathrm{V}$ průběhu těchto let docházelo k vývoji počtu bank, banky vznikaly, zanikaly, fúzovaly, přejmenovávaly se a měnily právní status. V př́ípadě, že banka během tohoto období zanikla a ztratila licenci, je při testování používán poslední název. U všech ostatních bank je relevantní název z roku 2009. Použitá data jsou čerpána z databáze BankScope (nekonsolidované účetní výkazy, metodika IFRS) s podrobnými finančními údaji za mnoho bankovních domů, které byly v hojné míre doplněny a dopočítány na základě informací z výročních zpráv bank, dále bylo čerpáno z databáze České národní banky, Českého statistického úřadu a Ministerstva financí České republiky.

Tabulka 1: Označení proměnných, jejich oč. vliv na riziko a NIM

\begin{tabular}{|c|c|c|c|c|}
\hline Zkratka & & Popis proměnné & \multirow[b]{2}{*}{ 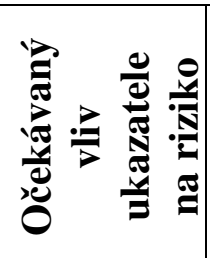 } & \multirow[b]{2}{*}{ 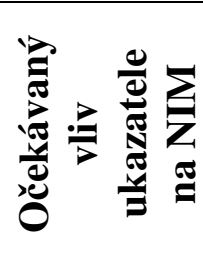 } \\
\hline NIM & & čistá úroková marže & & \\
\hline E1 & $\begin{array}{l}\text { ukazatel } \\
\text { kapitálového } \\
\text { rizika }\end{array}$ & základní kapitál / celková aktiva & - & + \\
\hline $\mathrm{E} 2$ & $\begin{array}{l}\text { ukazatel } \\
\text { kapitálového } \\
\text { rizika }\end{array}$ & $\begin{array}{l}\text { základní kapitál / úvěry a pohledávky za } \\
\text { klienty }\end{array}$ & - & + \\
\hline E3 & $\begin{array}{l}\text { ukazatel } \\
\text { kapitálového } \\
\text { rizika }\end{array}$ & $\begin{array}{c}\text { základní kapitál / (závazky vůči klientům } \\
\text { + závazky vǔči bankám + finanční } \\
\text { závazky z obchodování) }\end{array}$ & - & + \\
\hline E4 & $\begin{array}{l}\text { ukazatel } \\
\text { kapitálového } \\
\text { rizika }\end{array}$ & základní kapitál / závazky celkem & - & + \\
\hline L1 & $\begin{array}{l}\text { ukazatel } \\
\text { rizika } \\
\text { likvidity }\end{array}$ & $\begin{array}{l}\text { úvěry a pohledávky za klienty se } \\
\text { splatností do } 1 \text { roku / celková aktiva }\end{array}$ & - & $=$ \\
\hline $\mathrm{L} 2$ & $\begin{array}{l}\text { ukazatel } \\
\text { rizika } \\
\text { likvidity }\end{array}$ & $\begin{array}{l}\text { úvěry a pohledávky za klienty se } \\
\text { splatností do } 1 \text { roku / (závazky vǔči } \\
\text { klientům + závazky vůči bankám + } \\
\text { finanční závazky z obchodování) }\end{array}$ & - & - \\
\hline
\end{tabular}

\footnotetext{
${ }^{5}$ ARTL, J; ARTLOVÁ, M. Ekonomické časové řady, Praha: Grada Publishing a.s., 2007, s. 125-158. ISBN $978-$ 80-247-1319-9.
} 


\begin{tabular}{|c|c|c|c|c|}
\hline L3 & $\begin{array}{l}\text { ukazatel } \\
\text { rizika } \\
\text { likvidity }\end{array}$ & $\begin{array}{l}\text { úvěry a pohledávky za klienty se } \\
\text { splatností do } 1 \text { roku / (závazky vưči } \\
\text { klientům + závazky vǔči bankám + } \\
\text { finanční závazky z obchodování + } \\
\text { emitované cenné papíry + derivátové } \\
\text { finanční nástroje) }\end{array}$ & - & - \\
\hline L4 & $\begin{array}{l}\text { ukazatel } \\
\text { rizika } \\
\text { likvidity }\end{array}$ & $\begin{array}{l}\text { aktiva se splatností do } 1 \text { roku / (závazky } \\
\text { vưči klientům + závazky vůči bankám + } \\
\text { finanční závazky z obchodování) }\end{array}$ & - & - \\
\hline L5 & $\begin{array}{l}\text { ukazatel } \\
\text { rizika } \\
\text { likvidity }\end{array}$ & $\begin{array}{l}\text { aktiva se splatností do } 1 \text { roku / (závazky } \\
\text { vůči klientům + závazky vǔči bankám + } \\
\text { finanční závazky z obchodování + } \\
\text { emitované cenné papíry + derivátové } \\
\text { finanční nástroje) }\end{array}$ & - & - \\
\hline $\mathrm{C} 1$ & $\begin{array}{l}\text { ukazatel } \\
\text { kreditního } \\
\text { rizika }\end{array}$ & $\begin{array}{l}\text { rezervy na pohledávky z úvěrů se } \\
\text { selháním dlužníka / (úvěry a pohledávky } \\
\text { za klienty + rezervy na pohledávky } \\
\text { z úvěrů se selháním dlužníka) }\end{array}$ & - & - \\
\hline $\mathrm{C} 2$ & $\begin{array}{l}\text { ukazatel } \\
\text { kreditního } \\
\text { rizika }\end{array}$ & $\begin{array}{l}\text { (odpisy, tvorba a použití opravných } \\
\text { položek a rezerv k pohledávkám a } \\
\text { zárukám - rozpuštění opravných položek } \\
\text { a rezerv k pohledávkám a zárukám, } \\
\text { výnosy z dříve odepsaných pohledávek) / } \\
\text { čistý úrokový výnos }\end{array}$ & + & + \\
\hline C3 & $\begin{array}{l}\text { ukazatel } \\
\text { kreditního } \\
\text { rizika }\end{array}$ & $\begin{array}{l}\text { rezervy na pohledávky z úvěrů se } \\
\text { selháním dlužníka / pohledávky z úvěrů } \\
\text { se selháním dlužníka }\end{array}$ & - & - \\
\hline $\mathrm{C} 4$ & $\begin{array}{l}\text { ukazatel } \\
\text { kreditního } \\
\text { rizika }\end{array}$ & $\begin{array}{c}\text { pohledávky z úvěrů se selháním dlužníka } \\
\text { / (úvěry a pohledávky za klienty + } \\
\text { rezervy na pohledávky z úvěrů se } \\
\text { selháním dlužníka) }\end{array}$ & + & + \\
\hline I & $\begin{array}{l}\text { ukazatel } \\
\text { úrokového } \\
\text { rizika }\end{array}$ & $\begin{array}{l}\text { čistá aktiva s přeceněním úrokové sazby } \\
\text { do } 1 \text { roku/ základní kapitál }\end{array}$ & - & - \\
\hline
\end{tabular}

\section{Pramen: autor podle různých zdrojů}

Ukazatelé označované zkratkou E1-E4 reprezentují kapitálové riziko. Ve všech případech se jedná o obdobnou konstrukci ukazatelů, vždy je porovnáván základní kapitál k položkám v aktivech či pasivech. V případě ukazatele E1 a E2 jde o poměr základního kapitálu $\mathrm{k}$ celkovým aktivům resp. k položce aktiv, klientským úvěrům. Ukazatelé E3 a E4 vyjadřují podíl základního kapitálu k položkám pasiv, zjednodušeně řečeno k depozitům a krátkodobým závazkům, resp. celkovým závazkům. Vycházíme-li z předpokladu, že vyšší kapitálová přiměřenost signalizuje trhu lepší odolnost a solventnost banky, pak lze předpokládat, že růst zmíněných ukazatelů povede ke snížení kapitálového rizika. ${ }^{6}$ Dostatečná kapitálová vybavenost banky snižuje potenciální riziko insolvence. Zároveň nižší kapitálové riziko vytváŕí tlak na snížení nákladů spojených se získáváním zdrojů, protože vkladatelé jsou

\footnotetext{
${ }^{6}$ KAŠPAROVSKÁ, V. a kol. Praha: C. H. Beck, 2006. Řízení obchodních bank: vybrané kapitoly, s. 7. ISBN: 80-7179-381-7.
} 
ochotni prostředky díky vyššímu pocitu bezpečí ukládat s nižším výnosem a to je faktor působící pozitivně na čistou úrokovou marži. Je-li bráno v potaz, že cizí kapitál bývá většinou levnější než kapitál vlastní, ${ }^{7}$ pak s rostoucí kapitálovou vybaveností banky rostou průměrné náklady na kapitál. Platí tedy, že snižování kapitálového rizika povede ke snaze banky tyto rostoucí náklady na kapitál řešit zvyšováním čisté úrokové marže. ${ }^{8}$ Lze očekávat, že růst ukazatelů E1-E4 způsobí zvýšení čisté úrokové marže.

Zkratkami L1-L5 jsou označeny ukazatelé vyjadřující riziko likvidity. Ukazatelé jsou konstruovány jako podíly krátkodobých likvidních aktiv a položek z bilance banky. Ukazatel L1 představuje poměr krátkodobých klientských úvěrů a celkových aktiv. Ukazatelé L2 a L3 vyjadřují podíl krátkodobých klientských úvěrů a depozit navýšených o závazky z obchodování, resp. depozit, závazků z obchodování, emitovaných cenných papírů a derivátů. Ukazatelé L4 a L5 jsou podílem krátkodobých aktiv a depozit navýšených o závazky z obchodování, resp. depozit, závazků z obchodování, emitovaných cenných papírů a derivátů. Ze shodné konstrukce ukazatelů lze vyvodit obdobný vztah k riziku a potažmo k čisté úrokové marži. Pokud ukazatelé reprezentující riziko likvidity rostou, znamená to, že se zvyšuje podíl likvidních aktiv na položkách bilance. Drží-li banka v bilanci rychle likvidní aktiva, riziko likvidity klesá, růst hodnoty ukazatelů L1-L5 tudíž způsobuje snížení rizika likvidity. Zároveň je třeba poznamenat, že rychle likvidní aktiva přinášejí nižší výnos, což je v rozporu se snahou banky dosáhnout maximálního zisku. ${ }^{9}$ Dochází tedy k tlaku na snížení likviditní prémie v čisté úrokové marži. Je možné konstatovat, že růst ukazatelů L1-L5 bude př́íčinou snížení čisté úrokové marže. ${ }^{10}$

Ukazatelé, které jsou vyjádřeny zkratkami C1-C4 označují kreditní riziko. Na rozdíl od ukazatelů reprezentujících kapitálové riziko a riziko likvidity není konstrukce ukazatelů kreditního rizika ve všech př́padech stejná, tudíž vliv na riziko a na čistou úrokovou marži je odlišný. Ukazatel $\mathrm{C} 1$ představuje poměr rezerv na pohledávky z úvěrů se selháním dlužníka a klientských úvěrů zvýšených o rezervy na pohledávky z úvěrů se selháním dlužníka. Ukazatel C2 je podíl opravných položek a čistého úrokového výnosu, ukazatel C3 porovnává rezervy na pohledávky z úvěrů se selháním dlužníka s pohledávkami z úvěrů se selháním dlužníka. Ukazatel C4 vyjadřuje poměr pohledávek z úvěrů se selháním dlužníka a klientských úvěrů zvýšených o rezervy na pohledávky z úvěrů se selháním dlužníka. Konstrukce ukazatelů C1 a C3 je obdobná, jsou srovnávány rezervy s klientskými úvěry, resp. úvěry se selháním dlužníka. Jestliže je bráno v potaz, že rezervy na pohledávky z úvěrů se selháním dlužníka vytváří banka dopředu na krytí potenciálního kreditního rizika, pak platí, že čím vyšších hodnot tyto ukazatelé dosahují, tím nižší bude potenciální kreditní riziko. Vycházíme-li z předpokladu, že riziko a výnosnost tvoří spojité nádoby, ${ }^{11}$ pak čím menší je riziko ztráty,

\footnotetext{
${ }^{7}$ SYNEK, M. a kol. Praha: Grada Publishing a.s., 2007. Manažerská ekonomika, s. 51-54. ISBN: 978-80-2471992-4.

${ }^{8}$ CLAEYS, S., VENNET, R. V. Determinants of bank interest margins in Central and Eastern Europe: A comparison with the West. Economic Systems, 2008, vol. 32, pp. 197-216. ISSN: 0939-3625; KASMAN, A., TUNC, G., VARDAR, G., OKAN, B. Consolidation and commercial bank net interst margine: Evidence from the old and new European Union members and candidate countries. Economic Modelling, 2010, vol. 27, pp. 648655. ISSN: 02649993; ANGBANZO, L. Commercial bank net interest margins, default risk, interest-rate risk and off-balance sheet banking. Journal of Banking and Finance, 1997, vol. 21, pp. 55-87. ISSN: 0378-4266.

${ }^{9}$ KAŠPAROVSKÁ, V. a kol. Praha: C. H. Beck, 2006. Řízení obchodních bank: vybrané kapitoly, s. 129-137. ISBN: 80-7179-381-7.

${ }^{10}$ ANGBANZO, L. Commercial bank net interest margins, default risk, interest-rate risk and off-balance sheet banking. Journal of Banking and Finance, 1997, vol. 21, pp. 55-87. ISSN: 0378-4266; DRAKOS, K. Assessing the success of reform in transition banking 10 years later: an interest margins analysis. Journal of Policy Modeling, 2003, vol. 25, pp. 309-317. ISSN: 0161-8938.

${ }^{11}$ SYNEK, M. a kol. Manažerská ekonomika, Praha: Grada Publishing a.s., 2007, s. 309. ISBN: 978-80-247-1992-4.
} 
tím menší je potenciální výnos. Jestliže banka podstupuje nižší riziko, tím nižší je riziková prémie, která by se měla odrazit v čisté úrokové marži. Lze předpokládat, že poroste-li hodnota ukazatelů $\mathrm{C} 1$ a $\mathrm{C} 3$, dojde k poklesu čisté úrokové marže. Ukazatelé $\mathrm{C} 2$ a $\mathrm{C} 4$ jsou založeny na jiném principu. Srovnáváme tvorbu opravných položek resp. pohledávky z úvěrů se selháním dlužníka k položkám z výsledovky resp. bilance, řešíme tedy náklady související s již existujícími problematickými úvěry resp. množství problematických úvěrů. $Z$ tohoto lze usuzovat, že porostou-li hodnoty těchto ukazatelů, poroste kreditní riziko. Pokud platí vzájemný vztah rizika a výnosů, čím vyšší je riziko, tím vyšší je potenciální výnos, pak by banka s rostoucím rizikem měla požadovat vyšší rizikovou prémii, která by se měla projevit v nárůstu výše čisté úrokové marže. Čím vyšší je pravděpodobnost nesplácení půjček a tím i ztráty kapitálu a úroků, tím vyšší riziková prémie by měla být požadována. ${ }^{12}$ Poskytují-li banky rizikovější úvěry, požadují vyšší čistou úrokovou marži jako kompenzaci podstoupení vyššího kreditního rizika. ${ }^{13}$ Následkem růstu hodnoty ukazatelů C2 a C4 bude zvýšení čisté úrokové marže.

Ukazatel definovaný symbolem I reprezentuje úrokové riziko. Tento ukazatel vyjadřuje poměr čistých aktiv s přeceněním úrokové sazby do jednoho roku a základního kapitálu. Čistá aktiva s přeceněním úrokové sazby do jednoho roku jsou rozdílem aktiv a pasiv s přeceněním úrokové sazby do jednoho roku. Drží-li banka ve své bilanci aktiva s delší dobou splatnosti, vystavuje se vyššímu potenciálnímu úrokovému riziku, analogicky tedy platí, že čím více krátkodobými aktivy banka disponuje, tím nižší je potenciální úrokové riziko. Pro potřeby výpočtu úrokového rizika bylo nezbytné upřesnit pojem krátkodobá aktiva a krátkodobá pasiva na aktiva a pasiva s přeceněním úrokové sazby do jednoho roku. Platí-li, že v krátkém období jsou v podstatě všechna aktiva na změny úrokových sazeb necitlivá, pak tedy lze konstatovat, že čím více aktiv s přeceněním do jednoho roku bude banka držet, tím menšímu úrokovému riziku se bude její portfolio vystavovat. Zvýšení hodnoty ukazatele I bude znamenat snížení úrokového rizika. Zároveň je nutné dodat, snižuje-li banka riziko touto cestou, bude sílit tlak na snížení požadované rizikové prémie, protože s investicí do krátkodobých aktiv je spojen nižší výnos. Následkem bude snížení čisté úrokové marže. ${ }^{14}$ Nárůst hodnoty ukazatele I, který znamená snížení úrokového rizika, bude př́činou snížení čisté úrokové marže.

Základními panelovými identifikátory modelu jsou banky i a čas t. Kauzální vztah mezi výše uvedenými veličinami lze zjednodušeně zapsat takto:

$\mathrm{NIM}=f(\mathrm{E}, \mathrm{L}, \mathrm{C}, \mathrm{I})$

\footnotetext{
${ }^{12}$ HO, T., SAUNDERS, A. The determinants of banks interest margins: Theory and empirical evidence. Journal of Financial and Quantitative Analysis, 1981, vol. 16 (4), pp. 581-600, ISSN: 0022-1090.

${ }^{13}$ ANGBANZO, L. Commercial bank net interest margins, default risk, interest-rate risk and off-balance sheet banking. Journal of Banking and Finance, 1997, vol. 21, pp. 55-87. ISSN: 0378-4266; DRAKOS, K. Assessing the success of reform in transition banking 10 years later: an interest margins analysis. Journal of Policy Modeling, 2003, vol. 25, pp. 309-317. ISSN: 0161-8938.

${ }^{14}$ ANGBANZO, L. Commercial bank net interest margins, default risk, interest-rate risk and off-balance sheet banking. Journal of Banking and Finance, 1997, vol. 21, pp. 55-87, ISSN: 0378-4266; HO, T., SAUNDERS, A. The determinants of banks interest margins: Theory and empirical evidence. Journal of Financial and Quantitative Analysis, 1981, vol. 16 (4), pp. 581-600, ISSN: 0022-1090; DRAKOS, K. Assessing the success of reform in transition banking 10 years later: an interest margins analysis. Journal of Policy Modeling, 2003 , vol. 25, pp. 309-317. ISSN: 0161-8938.
} 


\section{Analýza vlivu bankovních rizik na čistou úrokovou marži}

Panelové testy jednotkového kořene prokázaly, že časové řady všech proměnných vstupujících do analýzy jsou stacionární a mohou tedy být použity v panelové regresi. Před samotnou analýzou bylo provedeno testování s použitím obou variant panelové regrese s fixními efekty i s náhodnými efekty. Aplikací Durbin-Wu-Hausmanova testu byla k analýze shromážděných panelových dat jednoznačně prokázána vhodnost použití panelového modelu s fixními efekty, přičemž průřezové efekty jsou fixní a časové efekty žádné.

K testování byl využit ekonometrický model, ve kterém byl testován vliv vybraných bankovních rizik na čistou úrokovou marži všech bank z celého bankovního sektoru. V rámci analýzy byly provedeny diagnostické testy reziduálních složek, ke klíčovým lze zařadit testy normality, multikolinearity a autokorelace.

Regresní rovnice, která je v počátku testování modelu využita, má následující podobu:

$$
\begin{gathered}
\mathrm{NIM}=\alpha+\beta_{1} \mathrm{E} 1_{i t}+\beta_{2} \mathrm{E} 2_{i t}+\beta_{3} \mathrm{E} 3_{i t}+\beta_{4} \mathrm{E} 4_{i t}+\beta_{5} \mathrm{~L} 1_{i t}+\beta_{6} \mathrm{~L} 2_{i t}+\beta_{7} \mathrm{~L} 3_{i t}+\beta_{8} \mathrm{~L} 4_{i t}+\beta_{9} \mathrm{~L} 5_{i t}+ \\
\beta_{11} \mathrm{C} 2_{i t}+\beta_{12} \mathrm{C} 3_{i t}+\beta_{13} \mathrm{C} 4_{i t}+\beta_{14} \mathrm{I}_{i t}+\delta_{i}+\varepsilon_{i t}
\end{gathered}
$$

kde NIM je výše čisté úrokové marže, která závisí na velikosti kapitálového rizika $\left(\mathrm{E}_{\mathrm{it}}\right)$, rizika likvidity $\left(\mathrm{L}_{\mathrm{it}}\right)$, kreditního rizika $\left(\mathrm{C}_{\mathrm{it}}\right)$ a úrokového rizika $\left(\mathrm{I}_{\mathrm{it}}\right)$, kde jsou konstanty specifické pro banku i a čas t. $\alpha$ je konstanta celého regresního modelu, $\delta_{i}$ jsou fixní efekty v i-tém pozorování (i-té bance), $\varepsilon_{\text {it }}$ vyjadřuje reziduální složku v čase $t$ a bance i.

Poté bylo přistoupeno k provedení úprav a postupnému odstranění statisticky nevýznamných proměnných, až byla získána rovnice obsahující jeden optimální ukazatel reprezentující danou skupinu vybraných bankovních rizik. Tuto rovnici lze obecně vyjádřit takto:

$\mathrm{NIM}=\alpha+\beta_{1} \mathrm{Ex}_{i t}+\beta_{2} \mathrm{Lx}_{i t}+\beta_{3} \mathrm{Cx}_{i t}+\beta_{4} \mathrm{I}_{i t}+\delta_{i}+\varepsilon_{i t}$

Při postupném odstraňování proměnných bylo vycházeno z výsledků testování multikolinearity a autokorelace. Nejprve byly odstraněny proměnné s nejvyšší mírou korelace L1 a L3 a poté byly postupně vyřazeny statisticky nevýznamné proměnné C1, C4, E4, L5, L2, C1, E2 a E3 (přesně v tomto pořadí). K rozhodování a vyhodnocení byly využity výsledky diagnostických testů určujících nadbytečnost ukazatelů. Dále bylo postupováno na základě informačních kritérií, mezi která patř́i Akaike kritérium, Schwarz kritérium a Hannan-Quinn kritérium.

\subsection{Odhadovaný ekonometrický model}

V tomto modelu je testován vliv vybraných bankovních rizik na čistou úrokovou marži všech bank z celého bankovního sektoru. Po provedení všech nezbytných úprav a testů nabyla rovnice modelu následující podoby:

$\mathrm{NIM}=\alpha+\beta_{1} \mathrm{E}_{i t}+\beta_{2} \mathrm{~L}_{i t}+\beta_{3} \mathrm{C} 3_{i t}+\beta_{4} \mathrm{I}_{i t}+\delta_{i}+\varepsilon_{i t}$

kde NIM je výše čisté úrokové marže, kterou ovlivňuje kapitálové riziko vyjádřené ukazatelem E1, riziko likvidity měřené ukazatelem L4, dále riziko kreditní, které je vyjádřené pomocí ukazatele C3 a riziko likvidity I (konstanty jsou specifické pro banku $i$ a čas $t$ ). $\alpha$ je konstanta celého regresního modelu, $\delta_{i}$ jsou fixní efekty v $i$-tém pozorování ( $i$-té banky), $\varepsilon_{i t}$ 
vyjadřuje reziduální složku $\mathrm{v}$ čase $t$ a bance $i$. Tabulka 1 prezentuje odhad testovaného modelu.

Tabulka 2: Odhad ekonometrického modelu

\begin{tabular}{|l|c|c|}
\hline \multicolumn{1}{|c|}{ Proměnná } & Koeficient & Směrodatná odchylka \\
\hline Konstanta $\alpha$ & $2,3274^{*}$ & 0,1514 \\
\hline E1 & $0,0381^{*}$ & 0,0100 \\
\hline L4 & $-0,0030^{* *}$ & 0,0015 \\
\hline C3 & 0,0004 & 0,0013 \\
\hline I & 0,0004 & 0,0004 \\
\cline { 1 - 2 } Upravený $\mathrm{R}^{2}$ & 0,7688 \\
\cline { 1 - 2 } Durbin-Watson test & 1,9709 & \\
\cline { 1 - 2 } Počet pozorování & 175 & \\
\hline
\end{tabular}

*, ** označuje signifikantní koeficient na 1\% (resp. 5\%) hladině statistické významnosti

\section{Pramen: výpočty autora}

Z výsledných hodnot odhadnutých regresních koeficientů v Tabulce 2 vyplývá, že mezi závislou proměnnou a nezávislými proměnnými existuje pouze velmi nepatrná funkční závislost. Na základě hodnoty odhadnutého parametru lze usuzovat na nízkou funkční závislost čisté úrokové marže na E1. S růstem hodnoty ukazatele E1 o 1 procentní bod je spojeno zvýšení čisté úrokové marže o $0,04 \%$. V prrípadě hodnoty odhadovaného parametru u proměnné L4 se také jedná o velice nízkou funkční závislost čisté úrokové marže na L4. Vzroste-li hodnota ukazatele L4 o 1 procentní bod dojde ke snížení čisté úrokové marže o $0,003 \%$. V souvislosti s hodnotou odhadnutého parametru lze konstatovat velmi nízkou funkční závislost čisté úrokové marže také na C3. Růst hodnoty ukazatele C3 o 1 procentní bod je spojen se zvýšením čisté úrokové marže o 0,0004 \%. Na základě hodnoty odhadnutého parametru proměnné I lze také usuzovat na velice nízkou funkční závislost čisté úrokové marže na I. S růstem hodnoty ukazatele I o 1 procentní bod je spojeno zvýšení čisté úrokové marže o $0,0004 \%$.

Vliv proměnné E1 je statisticky významný na $1 \%$ hladině významnosti, vliv proměnné L4 je statisticky významný na standardně používané $5 \%$ hladině významnosti. Vliv proměnných C3 a I není statisticky významný na žádné standardní hladině významnosti. Z hodnoty Durbin-Watsonova testu lze odvodit, že rezidua netrpí autokorelací. Přiléhavost modelu skutečnosti, tzn. objasnitelnost vlivu vybraných bankovních rizik na čistou úrokovou marži, vyjádřenou upraveným koeficientem determinace $\mathrm{R}^{2}$, dosahuje $77 \%$. Graf 1 znázorn̆uje rozdíly mezi odhadnutými (Fitted) a skutečnými hodnotami (Actual), přičemž odchylky (Residual) jsou zobrazeny modře. 
Graf 1: Odhadnuté hodnoty a reziduální složka modelu

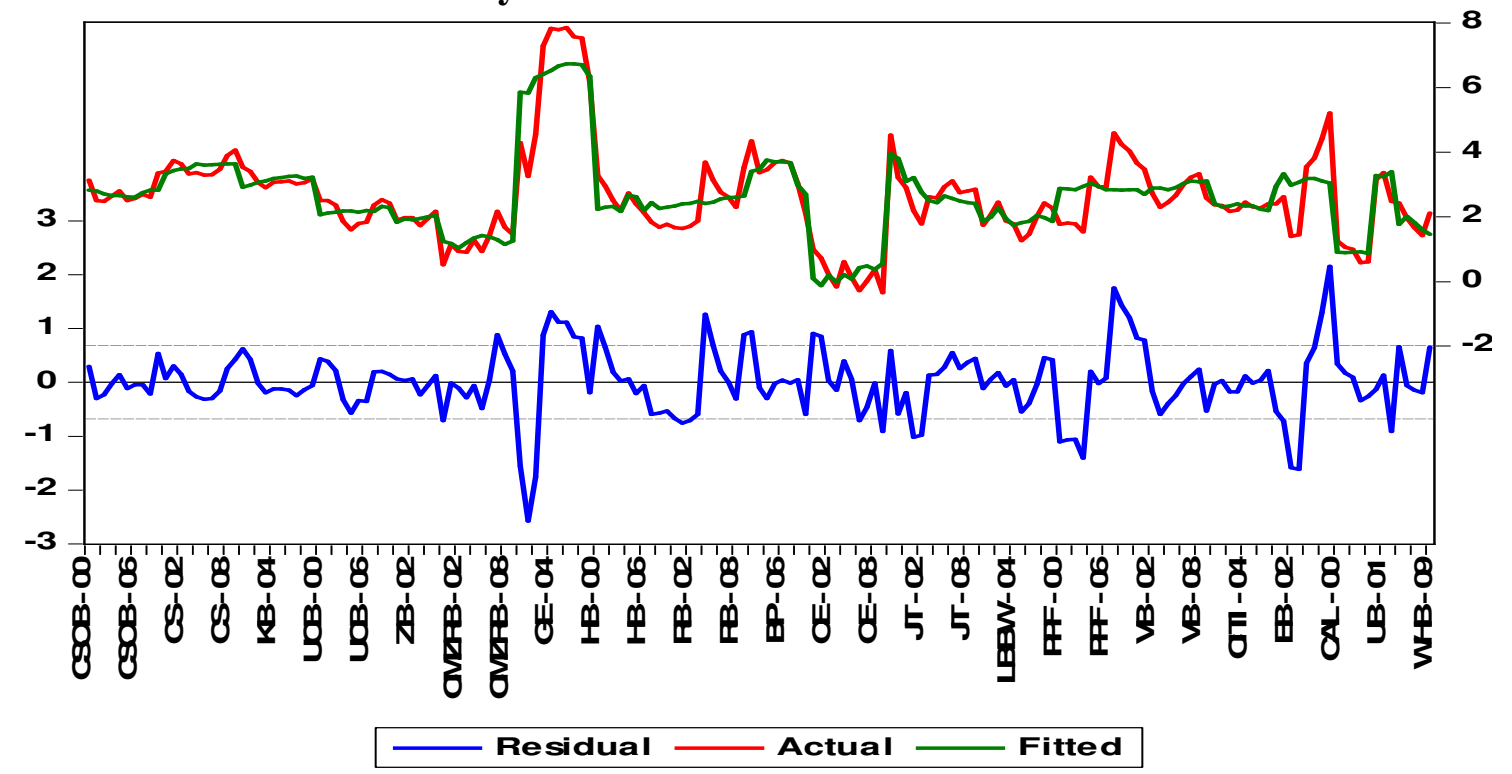

Pramen: výpočty autora

\subsection{Souhrn výsledků odhadovaného modelu}

Na základě výsledků odhadovaného modelu lze jednoznačně konstatovat, že závislost čisté úrokové marže na vybraných bankovních rizicích je minimální. Testovaný model reprezentuje celý bankovní sektor a statisticky významné jsou ukazatelé představující kapitálové riziko a riziko likvidity. Přestože je z výsledků analýzy patrné, že vliv kapitálového rizika na čistou úrokovou marži je zanedbatelný, lze konstatovat, že s růstem hodnoty ukazatele kapitálového rizika E1, bude mít čistá úroková marže tendenci se zvyšovat. Dostatečná kapitálová vybavenost banky vysílá trhu pozitivní signál o vy̌̌ší odolnosti banky vůči riziku insolvence a vkladatelé se zbavují obavy spojené s investicí, získávají vyšší komfort a jsou ochotni půjčit bance své prostředky s nižším výnosem. Vyšší kapitálová přiměřenost tedy snižuje kapitálové riziko, posiluje důvěryhodnost banky a tím vytváří tlak na snižování nákladů spojených s depozity. Nižší náklady spojené se získáním zdrojů se pozitivně promítají do výše čisté úrokové míry. Zároveň je nutné mít na zřeteli fakt, že s rostoucí kapitálovou vybaveností banky rostou průměrné náklady na kapitál a zvyšuje se tlak akcionářủ na vyšší výnosy, protože cizí kapitál je ve většině případů levnější než kapitál vlastní. Zvyšující se průměrné náklady na kapitál a sílící požadavky akcionářů na výnosy, se banka bude snažit řešit zvyšováním čisté úrokové marže. Jak již bylo řečeno, vliv rizik na čistou úrokovou marži je nízký a riziko likvidity není výjimkou. Nicméně testování prokázalo, že dojde-li k růstu hodnoty ukazatele likvidity L4, bude čistá úroková marže vystavena mírnému poklesu, protože držení rychle likvidních aktiv je spojeno s nižším výnosem a je v rozporu se snahou banky dosáhnout maximálního zisku. Jestliže se banka snaží minimalizovat riziko likvidity prostřednictvím rychle likvidních aktiv, dostává se do rozporu s paralelní snahou dosahovat co nejvyšší rentability. Je tedy zřejmé, že pokud banka udržuje vysokou likviditu, nemůže absolutizovat cíl dosáhnout maximálních výnosů, protože př́liš vysoká likvidita snižuje výnosy. Roste-li hodnota ukazatele L4, vzniká tlak na snížení likviditní prémie v čisté úrokové marži. 


\subsection{Srovnání výsledků se závěry předchozích studií}

Autoři mezinárodních studií a odborných publikací týkajících se determinantů čisté úrokové marže zkoumali a posuzovali vliv nejrůznějších faktorů na čistou úrokovou marži bank. Nejednalo se pouze o vztah celé škály vybraných rizik reprezentovaných řadou ukazatelů různé konstrukce a NIM, ale také o makroekonomické veličiny typu tempa růstu hrubého domácího produktu, míry inflace, volatility úrokové míry a dále o specifické ukazatele vyjadřující míru koncentrace a konkurence bankovního sektoru, tržní podíl bank, provozní náklady, velikost bankovních transakcí, alternativní náklady a kvalitu managementu. Ve studiích zabývajících se danou problematikou byla analyzována data vybraných bank různých velikostí, zastupujících řadu geografických oblastí a zemí, zkoumaných v odlišných časových obdobích. $Z$ tohoto důvodu nebyly výsledky a závěry ve všech př́ípadech zcela srovnatelné. Nicméně i přes tuto skutečnost byly z vědeckých statí a odborných článků získány relevantní a srovnatelné informace, které mohly být porovnány s našimi závěry, teoretickými úvahami a předpoklady. Všichni tito autoři se ve svých výzkumech shodli, že zvýšení kreditního, likviditního a úrokového rizika mělo za následek rưst čisté úrokové marže. Naopak, došlo-li k nárůstu kapitálového rizika, následovalo snížení čisté úrokové marže. K rozdílným závěrům dospěli tito autoři pouze v oblasti významnosti determinantů čisté úrokové marže, což je zapříčiněno již zmíněnými rozdílnými vstupními daty. Tyto závěry se plně shodují s výsledky naší analýzy a potvrzují teoretické a empirické předpoklady.

\section{Závěr}

Přestože naší analýzou nebyla prokázána významná vazba mezi vybranými bankovními riziky a čistou úrokovou marží bank českého bankovního sektoru, může zpracovaná studie poskytnout námět pro navazující výzkum, který by mohl rozšririt a doplnit současné výsledky a závěry. $\mathrm{V}$ této souvislosti je potřeba zmínit možný dopad nové regulace v souvislosti s Basel III, která může pozitivně ovlivnit řízení rizik. Jelikož základem Basel III je posílení kapitálové přiměřenosti, lze tedy se snižujícím se kapitálovým rizikem očekávat prostor pro rưst čisté úrokové marže. Zároveň je nutné dodat, že nově zaváděná pravidla Basel III obsahují zpřísněné požadavky na likviditu bank. Toto opatření by mohlo mít naopak vliv na snížení čisté úrokové marže, protože s držbou likvidních aktiv a pasiv je obecně spojen nižší výnos. Domnívám se, že prostor pro zkoumání vzájemných vztahů bankovních rizik a ziskovostí bank je značný a počet studií zabývajících se tímto tématem je nedostatečný. $\mathrm{V}$ př́ípadě bankovních sektorů zemí střední a východní Evropy a rozvíjejících se trhů obecně, je výzkum zaměřený na spojitost rizik a fungováním bank minimální. Je-li bráno v úvahu, že fatální selhání řízení rizik zapříčinilo nedávnou finanční krizi srovnatelnou s krizí ze trricátých let minulého století, která se následně přelila do celosvětové ekonomiky a paralyzovala všechna hospodářská odvětví, pak je ve světě poznamenané touto krizí vytvoření spolehlivě fungujícího systému identifikace, sledování a řízení rizik absolutní nezbytností. Lze konstatovat, že s profesionálním a odpovědným řízením rizik úzce souvisí dobře fungující a ziskový bankovní sektor, který vytváří předpoklad zdravého vývoje celé ekonomiky. Z tohoto pohledu je důležité pokračovat $\mathrm{v}$ dalším zkoumání vlivů rizik na rentabilitu bank.

\section{Literatura:}

[1] ANGBANZO, L. Commercial bank net interest margins, default risk, interest-rate risk and off-balance sheet banking. Journal of Banking and Finance, 1997, vol. 21, pp. 5587, ISSN 0378-4266.

[2] ARTL, J., ARTLOVÁ, M. Ekonomické časové řady, Praha: Grada Publishing a. s., 2007. ISBN 978-80-247-1319-9. 
[3] CLAEYS, S., VENNET, R. V. Determinants of bank interest margins in Central and Eastern Europe: A comparison with the West. Economic Systems, 2008, vol. 32, pp. 197216. ISSN 0140-9883.

[4] DRAKOS, K. Assessing the success of reform in transition banking 10 years later: an interest margins analysis. Journal of Policy Modeling, 2003, vol. 25, pp. 309-317. ISSN 0161-8938.

[5] HO, T., SAUNDERS, A. The determinants of banks interest margins: Theory and empirical evidence. Journal of Financial and Quantitative Analysis, 1981, vol. 16 (4), pp. 581-600, ISSN 0022-1090.

[6] JÍLEK, J. Finanční rizika, Praha: Grada Publishing a. s., 2000. ISBN 80-7169-579-3.

[7] KASMAN, A., TUNC, G., VARDAR, G., OKAN, B. Consolidation and commercial bank net interest margins: Evidence from the old and new European Union members and candidate countries. Economic Modelling, 2010, vol. 27 (3), pp. 648-655. ISSN 02649993.

[8] KAŠPAROVSKÁ, V. a kol. Řízení obchodních bank: vybrané kapitoly. Praha: C. H. Beck, 2006. ISBN: 80-7179-381-7.

[9] NOVÁK, P. Analýza panelových dat, Praha: Acta Oeconomica Pragensia, 2007, roč. 15, č. 1, s. 71 - 78. ISSN 0572-3043.

[10] POLOUČEK, S. a kol. Bankovnictví, Praha: C. H. Beck, 2006. ISBN 80-7179-462-7.

[11] SYNEK, M. a kol. Manažerská ekonomika, Praha: Grada Publishing a.s., 2007. ISBN: 978-80-247-1992-4.

[12] VODOVÁ, P. Řizení finančních rizik A, Karviná: Slezská univerzita v Opavě Obchodně podnikatelská fakulta v Karviné, 2006. ISBN 80-7248-349-8.

\section{JEL C23, G21, G32}

\section{Ing. Marek Dohnal}

student doktorského studia

Obchodně podnikatelská fakulta v Karviné

Slezská univerzita v Opavě

Univerzitní náměstí 1934/3, 73340 Karviná

marek.dohnal@centrum.cz 